\title{
Download
}

UDC 911.3:30/33(477.8)

https://doi.org/10.17721/2308-135X.2020.60.73-85

Smochko Nataliia Mykhailivna,

Candidate of Geographical Sciences, Associate Professor, http://orcid.org/0000-0002-2440-5737 Mukachevo State University, Mukachevo, Ukraine,

e-mail: natazak@ukr.net

\section{LAND RESOURCE POTENTIAL OF THE TRANSCARPATHIAN REGION AS A FACTOR OF AGRICULTURAL MONOSYSTEM DEVELOPMENT}

The purpose of this work is to analyze the land resource potential of the Transcarpathian region and the main trends in the efficiency of its use. The study of land use optimization in the mountainous and foothills of the Carpathians is of particular importance. The specific climatic and morphological conditions of the region and the reorganization of land use exacerbate the problem of effective development of the agricultural sector and ecology of land reproduction.

Method. General scientific methods, including analysis, scientific synthesis, analytical method, methods of comparison and generalization been used in the study. To study the current state of land and resource potential of the Transcarpathian region, information from the Main Department of the State Geocadastre in the Transcarpathian region and statistical materials of 
the Main Department of Statistics in the Transcarpathian region have been used. To achieve this goal, comparative geographical and statistical research methods have been used.

Scientific novelty. The article highlights the trends, approaches and features of land use potential of the Transcarpathian region. Its spatial differentiation has been investigated, the component structure of the land fund of the Zakarpattia region has been analyzed and the intensity of the target use of the land resources of the region has been determined. A general assessment of the use of land resources of the Transcarpathian region has been done as a major factor in the development of agricultural monosystems and identified areas of its rational use. It has been determined that a characteristic feature of the land resources of the region is the low level of area use suitable for agricultural production, there is also a significant withdrawal of land for commercial and residential construction.

Practical meaning. The results of this study can be used in the educational process of educational institutions; in the development of state and regional programs for the development of the agricultural sector of the national economy; for the preparation of new regulatory, program and methodological documents.

Key words: land resource potential, land use, lands, agricultural lands, sown areas.

References:

1. Borshchevs'kyy P. P. Shlyakhy strukturnykh peretvoren' v ahropromyslovomu kompleksi / P. P. Borshchevs'kyy // Ekonomika APK. - 1995. - \# 1. - S. 68-74.

2. Horlachuk V. V. Rozvytok zemlekorystuvannya v Ukrayini / V. V. Horlachuk. - K.: Dovira, 1999. $-254 \mathrm{~s}$.

3. Hroshova otsinka zemel', 2020. Derzhavna sluzhba Ukrayiny z pytan' heodeziyi, kartohrafiyita kadastru. Ofitsiynyy sayt. [Elektronnyy resurs] - Rezhym dostupu:

https://land.gov.ua/icat/otsinka-zemel/ 
4. Derzhavna stratehiya rehional'noho rozvytku na 2021-2027 roky, zatverdzhena postanovoyu Kabinetu Ministriv Ukrayiny vid 5 serpnya 2020 r. \# 695. [Elektronnyy resurs] - Rezhym dostupu: https://zakon.rada.gov.ua/laws/show/695-2020-\%D0\%BF\#Text

5. Dopovid' Departamentu ekolohiyi ta pryrodnykh resursiv Zakarpat-s'koyi oblasnoyi derzhavnoyi administratsiyi «Pro stan navkolyshn'oho pryrodnoho seredovyshcha Zakarpat-s'koyi oblasti za 2019 rik». [Elektronnyy resurs] - Rezhym dostupu: https://ecozakarpat.gov.ua/?page_id=308

6. Zemel'nyy dovidnyk Ukrayiny: 2020. Infohrafichnyy dovidnyk. [Elektronnyy resurs] - Rezhym dostupu:

https://agropolit.com/storage/2020/Zemelniy_dovidnyk_2020.pdf?utm_source=mailchimp\&utm_ campaign=0300ccc2e 1 f0\&utm_medium=page

7. Lendyel M. A. Ahrarne vyrobnytstvo v Karpat-s'komu rehioni: suchasnyy stan, tendentsiyi, perspektyvy rozvytku: monohrafiya / M. A. Lendyel - Uzhhorod: Karpaty, 2006. -216 s.

8. Lysets'kyy A. S. Ahropromyslovyy kompleks: suchasnyy stan i perspektyvy rozvytku / A. S. Lysets'kyy // Rozmishchennya produktyvnykh syl i rehional'na ekonomika. - K.: KNEU, 2005. S. 449-500.

9. Novakovs'kyy L. Ya. Rehional'na zemel'na polityka / L. Ya. Novakovs'kyy, M. I. Shkvyr. - K.: Urozhay, 2006. - $133 \mathrm{~s}$.

10. Ofitsiynyy sayt derzhavnoyi sluzhby statystyky. [Elektronnyy resurs]. - Rezhym dostupu: httr://www.ukrstat.gov.ua/

11. Petrova L. Pryrodno-zapovidnyy fond Ukrayins'kykh Karpat / L. Petrova, P. Tretyak. [Elektronnyy resurs] - Rezhym dostupu:

http://dspace.nbuv.gov.ua/bitstream/handle/123456789/73661/20-Petrova.pdf?sequence=1 
12. Pytulyak M. Zemel'no-resursnyy potentsial Ternopil's'koyi oblasti ta efektyvnist' yoho vykorystannya v suchasnykh umovakh hospodaryuvannya / M. Pytulyak, M. Pytulyak // Naukovi zapysky, 2018. - \#1. - S. 190-196

13. Pop S. S. Pryrodni resursy Zakarpattya. - 3-e vyd. dopov. / S. S. Pop - Uzhhorod: «Karpaty», 2009. - 340 s.

14. Pryrodni bahat-stva Zakarpattya. / Uporyad. V. L. Bondar. - Uzhh.: Karpaty, 1987. - 284 s.

15. Rudenko V.P. Heohrafiya pryrodno-resursnoho potentsialu Ukrayiny. - L'viv: Svit, 1993. $240 \mathrm{~s}$.

16. Udovenko I. O. Otsinka ta prohnozuvannya vykorystannya zemel'no-resursnoho potentsialu terytoriyi: teoretyko-metodolohichnyy aspekt / I. O. Udovenko, M. V. Shemyakin, S. I.

Kononenko // Ahrosvit, 2020. - \# 21. - S. 61-70

Надійшла до редколегії 02.12.2020 